\title{
PENGARUH PERHATIAN KEPALA SEKOLAH DAN SIKAP AKHLAKUL KARIMA GURU TERHADAP HASIL PENDIDIKAN KARAKTER SANTRI DI PONDOK MODERN DARUSSALAM GONTOR
}

\section{Alvia Ismi Syukur}

How to cite : Syukur, Alvia Ismi., 2021. PENGARUH PERHATIAN KEPALA SEKOLAH DAN SIKAP AKHLAKUL KARIMA GURU TERHADAP HASIL PENDIDIKAN KARAKTER SANTRI DI PONDOK MODERN DARUSSALAM GONTOR. Jurnal Penelitian dan Penilaian Pendidikan. 3(1). 50-82.

To link to this article : https://doi.org/10.22236/jppp.v3i1.5907

C2021. The Author(s). This open access article is distributed under a Creative Commons Attribution (CC BY-SA) 4.0 license.

\section{Pry \\ Published Online on 12 Desember 2020 \\ https://journal.uhamka.ac.id/index.php/jppp}

View Crossmark data $₫$ 


\title{
PENGARUH PERHATIAN KEPALA SEKOLAH DAN SIKAP AKHLAKUL KARIMA GURU TERHADAP HASIL PENDIDIKAN KARAKTER SANTRI DI PONDOK MODERN DARUSSALAM GONTOR
}

\author{
Alivia Ismi Syukur ${ }^{1}$ \\ ${ }^{1}$ Universitas Muhammadiyah Prof DR HAMKA \\ E-mail: $\quad$ alvia.ismi@uhamka.ac.id ${ }^{\text {l) }}$
}

Received: 16 October 2020/ Accepted: 1 Desember 2020/ Published Online: 12 Desember 2020

\begin{abstract}
Abstrak
Tesis ini bertujuan untuk mengetahui pengaruh perhatian kepala sekolah dan sikap akhlakul karimah guru terhadap hasil pendidikan karakter santri di pondok modern Darussalam Gontor se-Jawa Timur. Responden penelitian ini berjumlah 110 wali kelas di Pondok Modern Darussalam Gontor Putra 1 yang terletak di Ponorogo, Jawa Timur dan Pondok Modern Darussalam Gontor Putri 1 yang terletak di Ngawi, Jawa Timur. Pesantren ini terkenal dengan tingkat kedisipilinannya yang tinggi. Untuk mengujihipotesis, penelitian ini menggunakan metode kuantitatif inferensial dan dianalisis menggunakan teknik analisis jalur. Temuan dalam penelitian ini menghasilkan $\mathrm{p} 21=0.425$, thitung $=4.878$ dan $\mathrm{p}$-value $=0.000<0.05$ yang berarti perhatian kepala sekolah berpengaruh langsung positif terhadap sikap akhlakul karimah guru. P31 = 0.243, thitung $=2.548$ dan -value $=0.006<0.05$ yang berarti perhatian kepala sekolah berpengaruh langsung positif terhadap hasil pendidikan karakter santri. $\mathrm{P} 32=0.291$, thitung $=3.054$ danp-value $=0.0015<0.05$ yang berarti sikap akhlakul karimah guru berpengaruh langsung positif terhadap hasil pendidikan karakter santri.
\end{abstract}

Kata kunci : perhatian kepala sekolah, sikap akhlakul karimah guru, hasil pendidikankarakter santri, analisis jalur, Pondok Modern Darussalam Gontor.

\begin{abstract}
This thesis aims to determine the effect of the attention of the principal and the moral attitude of the teacher on the results of character education for students in Darussalam Gontor modern boarding schools in East Java. Respondents to this study amounted to 110 homeroom teachers at Pondok Modern Darussalam Gontor Putra 1 located in Ponorogo, East Java and Pondok Modern Darussalam Gontor Putri 1 located in Ngawi, East Java. This pesantren is famous for its high level of discipline. To test the hypothesis, this study used inferential quantitative methods and analyzed using path analysis techniques. The findings in this study resulted in p21 $=0.425$, tcount $=4.878$ and $\mathrm{p}$-value $=0.000<0.05$, which means that the attention of the school principal has a positive direct effect on the teacher's moral attitude. P31 $=0.243$, tcount $=2.548$ and $\mathrm{p}$-value $=0.006<0.05$ which means the attention of the principal has a direct positive effect on the results of the character education of students. P32 $=0.291$, tcount $=3.054$ and p-value $=0.0015<0.05$, which means that the teacher's moral attitude has a direct positive effect on the results of students' character education.
\end{abstract}

Keywords: the attention of the principal, the attitude of the teacher's akhlakul karimah, the results of the character education of the students, path analysis, Pondok Modern Darussalam Gontor.

This is an open access article under the Creative Commons Attribution 4.0 International License 


\section{PENDAHULUAN}

Cerdas berkarakter merupakan slogan yang menjadi tren serta mengandung cita- cita dan tujuan pendidikan yang sering didengar pada beberapa tahun belakangan di Indonesia. Slogan tersebut selalu terngiang seakan mengisyaratkan gambaran generasi muda Indonesia di masa mendatang. Namun, dua kata tersebut menjadi sebuah tantangan yang cukup berat bagi pendidik untuk merealisasikannya. Agar cerdas berkarakter terealisasikan secara optimal pada generasi muda Indonesia, dibutuhkan usaha lebih bagi pendidik mengingat kenyataan bahwa tidak semua individu yang cerdas memiliki karakter kuat, begitu pula sebaliknya.

Kecerdasan itu sendiri merupakan gambaran dari kapasitas peserta didik dalam beradaptasi dan belajar melalui pengalaman serta kemampuannya dalam menyelesaikan masalah. Kecerdasan dapatdiukur dengan berbagai macam cara, salah satunya dengan mengerjakan soal-soal. Di sekolah, guru telah dianjurkan untuk membuat soal berbasis higher-order thinking skill atau biasa disebut soal HOTS guna menguji tingkat tersulit dari berpikir yaitu analisis, evaluasi dan mencipta. Soal HOTS bertujuan untuk menciptakan generasi yang memiliki daya nalar tinggi.

Namun, yang menjadi kegelisahan adalah apakah kecakapan berpikir akan diimbangi dengan karakter yang kuat? KEMENDIKBUD selain berupaya mewajibkan soal-soal HOTS juga mencanangkan program penguatan pendidikan karakter di sekolah,yang mana program pendidikan karakter semakin mendapat prioritas di Indonesia dengan diberlakukannya Peraturan Pemerintah No. 87 Tahun 2017 mengenai penguatan pendidikan karakter yang menjadi program ataupun gerakan pendidikan di sekolah demimemperkuat karakter peserta didik yang tidak hanya berfokus pada sekolah tetapi juga melibatkan kerja sama keluarga dan masyarakat dalam pembentukannya.

Penyelenggaraan program pendidikan karakter dilaksanakan dengan prinsip manajemen berbasis sekolah dan menjadi tanggung jawab penuh kepala sekolah dan guru sebagai pemenuhan beban kerja guru dan kepala sekolah. Diterapkannya soalsoal berbasis HOTS ditambah dengan penyisipan pendidikan karakter pada kurikulum pembelajaran dan segudang administrasi yang harus dikerjakan, cukup membuat guru kewalahandalam merealisasikannya ke dalam mata pelajaran.

Alivia Ismi Syukur titimun18@gmail.com凶

${ }^{1}$ Sekolah Pascasarjana Universitas Muhammadiyah PROF. DR. HAMKA

Syukur.alivia@gmail.com 
Pendidikan karakter menjadi fokus perhatian di Indonesia selaras dengan hasil pendidikan saat ini. Sering terjadi peristiwa anak-anak sekolah hingga orang dewasa membuang sampah sembarangan, tidak membudayakan antri, bersikap acuh, bahkan kurangnya hormat terhadap guru dan orang tua. Beberapa kasus yang cukup ekstrim menggambarkan bobroknya karakter siswa salah satunya terjadi di Manado pada akhir tahun 2019 silam. Seorang siswa menikam gurunya hingga tewas karena merasa kesal setelah mendapat teguran merokok. ${ }^{2}$ Berita ini cukup menyayat hati dunia pendidikan yang mana menggambarkan kurangnya rasa hormat siswa terhadap guru.

Penerapan pendidikan karakter dalam kurikulum diharapkan mampu mengembangkan pribadi siswa dalam bersikap dan mengambil keputusan sesuai dengannilai-nilai serta norma-norma yang berlaku baik dalam agama maupun masyarakat.Tentu saja, tujuan utamanya untuk menciptakan generasi yang cerdas berkarakter di masa mendatang. Cerdas berkarakter yang akhir-akhir ini menjadi tujuan pendidikan pemerintah ternyata sudah sejak lama dicanangkan oleh salah satu lembaga pendidikan Islam di Indonesia yaitu Pondok Modern Darussalam Gontor.

Pondok Modern Darussalam Gontor merupakan Pesantren tertua dan pertamayang mengusung sistem pendidikan pesantren modern di Indonesia. Berdiri sejak tahun 1926, Pondok Modern Darussalam Gontor sudah bertekad untuk melahirkan generasi yang tidak hanya cerdas secara ilmiah tetapi juga akhlak Al Qur'an sesuai dengansyariat Islam dengan salah satu mottonya yang berbunyi "jadilah ulama yang intelek, bukan intelek yang tahu agama". ${ }^{3}$ Dari sinilah peneliti berkeinginan untuk mengkaji pendidikan karakter santri di Pondok Modern Darussalam Gontor. Tidak dapat dipungkiri bahwa Pondok Modern Darussalam Gontor merupakan pesantren yang terkenal akan tingkat kedisiplinan yang tinggi. Dengan sistempendidikan 24 jam non stop, lembaga ini membangun pendidikan karakter dengan metode keteladan, pengarahan, pembiasaan, pelatihan dan partisipasi. $^{4}$

Pondok Modern Darussalam Gontor memiliki kurikulum tersendiri yang konsisten dan tidak pernahberubah hingga kini bernama Kulliyatul Mu'allimin Al Islamiyah (KMI) yang mana di dalamnya memiliki tujuan untuk mendidik santrisantrinya menjadi pendidik. Karena pesan kyai di setiap Pekan Khutbatul 'Arsy selalu berbunyi “di manapun kalian berada, kewajiban kalian untuk mengajar”.

\footnotetext{
2 Ireine. Buyung, (2019) "Murid Tusuk Guru hingga Tewas, Izin SMK Ichthus Manado Dicabut." https://m.detik.com/news/berita/d-4762662/murid-tusuk-guru-hingga-tewas-izin-smk-ichthus-manado-dicabut diakses pada 02 Februari 2020
} 
Kurikulum KMI terintegrasi antara ilmu agama dengan ilmu pengetahuan umum. Kurikulum ini tidak menerapkan sistem nilai Kriteria Ketentuan Minimal (KKM), sehingga berapapun nilai ujian yang didapat santri tercantum dengan nyata diraport. Maka dari itu sekitar 10-25\% dari setiap angkatan bisatinggal kelas, meskipun begitu kurikulum ini tetap konsisten dan tidak pernah berubah sejak awal mula didirikannya Pondok Modern Darussalam Gontor hingga saat ini.

Selain dari kurikulum yang berbeda, fasilitas yang ada di Pondok Modern Darussalam Gontor bisa dikatakan sangat sederhana dan tidak menyediakan fasilitas mewah nan mahal ataupun fasilitas mutakhir. Pondok Modern Darussalam Gontor memiliki beberapa laboratorium seperti laboratorium komputer, bahasa, keputrian, selain itu adapula perpustakaan, namun fasilitas yang ada sangat sederhana jika dibandingkan dengan pesantren terkenal maupun sekolah-sekolah besar lainnya.

Meskipun Pondok Modern Darussalam Gontor merupakan pesantren yang besar dan tersebar di Indonesia, biaya yang dikeluarkan santri per bulannya terbilang cukup murah dengan pendidikan yang berkualitas. Biaya yang murah dengan kualitas yang bagus bisa didapat karena Gontor mengangkat guru dari alumninya sendiri, para guru mengajar dengan tulus dan ikhlas tanpa menuntut upah. Selain itu Gontor juga memilikibeberapa unit usaha dan sawah sebagai sumber ekonomi yang dapat memasok keberlangsungan kehidupan tanpa mengharapkan dana dari pihak luar.

Biaya yang murah, fasilitas seadanya dan kurikulum yang berbeda namun konsisten tidak menghalangi Pondok Modern Darussalam Gontor untuk melahirkan generasi yang berkualitas, baik dari segi intelektual maupun karakter. Beberapa contoh alumni Pondok Modern Darussalam Gontor yang berkiprah baik nasional maupun Internasional seperti Bapak Sirajuddin Muhammad Din Syamsudin atau biasa dikenal dengan Din Syamsudin yang merupakan ketua organisasi Muhammadiyah, ketua CDCC, ketua World Peace Forum dan sebagainya. Bahkan, Haedar Nasir mengatakan bahwa sosok karakter Din Syamsudin perlu dijadikan revolusi mental dalam konteks kebangsaan. Selain itu, adapula Prof. Dr. H. M. Roem Rowi, MA., beliau merupakan guru besar di program pascasarjana UIN Sunan Ampel, Surabaya. Dr. H. Hidayat Nur Wahid, MA., selaku ketua Majelis Permusyawaratan Rakyat ke-11, serta masih banyak lagi alumni Pondok Modern Darussalam Gontor yang berkualitas baik secara intelektualmaupun karakter. Slogan yang diciptakan pemerintah untuk menciptakan generasi cerdas berkarakter terealisasikan dalam pendidikan Gontor yang notabene secara kurikulum tidak sama dengan pemerintah bahkan tidak mengharapkan kucuran dana dari 
pemerintah. Hasil pendidikan karakter santri yang sebagian besar dikenal baik, tidak lepas dari peran kepala sekolah yang memperhatikan secara rinci kurikulum pendidikan karakter selama proses pembelajaran.

Perhatian kepala sekolah merupakan pemusatan pikiran dan kemauan yang dilakukan secara sadar dan sengaja yang dilakukan kepala sekolah baik kepada peserta didik, pendidik, maupun staff yang ada di sekolah. Perhatian kepala sekolah merupakan suatu bentuk kesadaran kepala sekolah untuk mengamati masyarakat sekolah sesuai dengan fungsi dan tugas pokoknya. Perhatian dari kepala sekolah sangat diperlukan demi terciptanya keseimbangan dalam kehidupan sekolah agar masyarakat sekolah dapat maju dan berkembang sesuai dengan visi dan misi yang ada. Karenasesungguhnya kepala sekolah memiliki tugas pokok sebagai manajer, supervisor, edukator, pemimpin, inovator dan motivator. Selain memperhatikan perkembangan peserta didik baik dalam segi kognitif, efektif maupun psikomotorik, kepala sekolah hendaknya juga memperhatikan sikap pendidiknya yaitu guru.

Sikap guru merupakan ranah yang penting untuk menjadi perhatian karena pada hakikatnya guru yaitu "digugu dan ditiru" yang berarti seorang guru dapat dipercaya dan ditiru baik dari segi pengetahuan maupun sikap. Tentunya sikap yang baik harus sesuai dengan asas moral dan nilai-nilai agama. Dalam agama Islam sikap yang baik biasa disebut dengan akhlakul karimah yang berarti perilaku terpuji, sehingga guru sendiri merupakan tauladan dan panutan bagi santrinya. Guru diharapkan mampu menyampaikan ilmu pengetahuan dan keterampilan bagi santrinya. Selain itu diharapkan pula mampu bertingkah laku sesuai dengan nilainilai moral dan agama. Sikap akhlakul karimah merupakan tata cara berperilaku yang sesuai dengan apa yang termaktub dalam Al Qur'an yang tercermin dalam sikap Rasulullah SAW.

Sikap akhlakul karimah guru merupakan aspek penting dalam mempengaruhi pengembangan hasil pendidikan karakter santri. Namun, sikap tersebut perlu didukung dengan perhatian kepala sekolah sebagai pemimpin utama dalam sekolah.

\footnotetext{
2 Pondok Modern Darussalam Gontor. 2017. Warta Dunia. Ponorogo : Darussalam Press. H : 98

3 M. Ihsan. Dacholfany. 2014. "Character Education Learning From Gontor”. Wafi Media Tama, Director General of Religious Affairs. Encyclopedia of Islam in Indonesia
} 
Perhatian kepala sekolah terhadap sikap akhlakul karimah guru membuat guru-guru selalu berusaha untuk menjaga sikapnya dan menjadi suri tauladan yang baik untuk peserta didiknya. Pada hakikatnya, peserta didik mengamati dan meniru perilaku gurunya. Tidak dapat dipungkiri jika pendidikan karakter akan tercapai jika guru memiliki sikap akhlakul karimah yang tak luput dari perhatian kepala sekolah. Hal inilah yang menjadi ketertarikan peneliti untuk mengkaji dengan segala keterbatasan fasilitas, murahnya biaya, dan perbedaan kurikulum yang dijalankan, Pondok Modern Darussalam Gontor mampu melahirkan generasi yang berkarakter terbukti dengan tiap tahun ajaran baru sekolah ini sangat diminati oleh masyarakat Indonesia yang bahkan dapat mencapai sekitar 3000 orang tua yang mendaftarkan anaknya untuk sekolahdisini.

Survei pendahuluan yang dilakukan peneliti melalui orang tua yang menyekolahkan anaknya di Pondok Modern Darussalam Gontor, Jawa Timur menghasilkan pernyataan bahwa alasan mereka memasukkan anaknya ke pesantren tersebut karena santri-santrinya memiliki sopan santun dan religiusitas yang tinggi, metode pembelajarannya pun mengintegrasikan ilmu agama dengan ilmu pengetahuan umum yang cukup, bahkan banyak alumninya yang sukses. Selain itu, karena sistemnyaadalah pondok yang mana santrinya diharuskan untuk menetap selama 24 jam penuh di dalam pengawasan pondok, orang tua merasa lebih aman untuk menyekolahkan anaknya di sana. ${ }^{5}$

Peneliti menyadari akan harapan masyarakat yang tinggi terhadap Pondok Modern Darussalam Gontor agar mampu mencetak generasi unggul, cerdas berkarakter dan memiliki kemampuan bersaing. Dengan demikian diperlukan perhatian penuh secara komprehensif dari kepala sekolah dan suri tauladan yang baik dari guru-gurunya sehingga mampu mengantarkan sekaligus mengembangkan kemampuan serta karakter santri sesuai dengan potensi yang dimilikinya. Karakter tidak bisa serta-merta terbentuk begitu saja dan tidak mungkin pula hanya dengan pembahasan melalui materi yang diajarkan dapat membentuk kekuatan karakter santrinya. Setidaknya dibutuhkan contoh sikap yang baik dari pendidiknya, sehingga sikap akhlakul karimah guru sangat diperlukan sebagai pendidik.

\section{METODE PENELITIAN}

Tujuan penelitian ini adalah untuk mengetahui pengaruh perhatian kepala sekolah dan sikap akhlakul karimah guru terhadap hasil pendidikan karakter santri di Pondok Modern Darussalam Gontor Jawa Timur. Pesantren dipilih karena merupakan tempat yang tepat sebagai garda penjaga moral bangsa dan basis utama bagi pembentukan karakter bangsa. ${ }^{6}$ Sedangkan Pondok Modern Darussalam Gontor dipilih karena memiliki tujuan menjadikan santri-santrinya ulama yang intelek bukan sekedar intelek yang tahu agama. ${ }^{7}$ Didalamnya santri-santri dididik 
untuk hidup mandiri dengan berbekal ilmu agama yang kuat dan terpaan kedisiplinan yang tinggi, sehingga dapat menanggulangi kemerosotan akhlak yang disebabkan oleh perkembangan zaman dan teknologi maupun pergaulan bebas yang jauh dari syariat agama, serta menjadikan karakter santri-santri nya kuat dengan segala kegiatan yang disuguhkan selama 24 jam.

Penelitian ini menggunakan pendekatan kuantitatif menggunakan metode survei kausal dengan teknik analisis jalur. Adapun konstelasi masalahnya sebagai berikut :

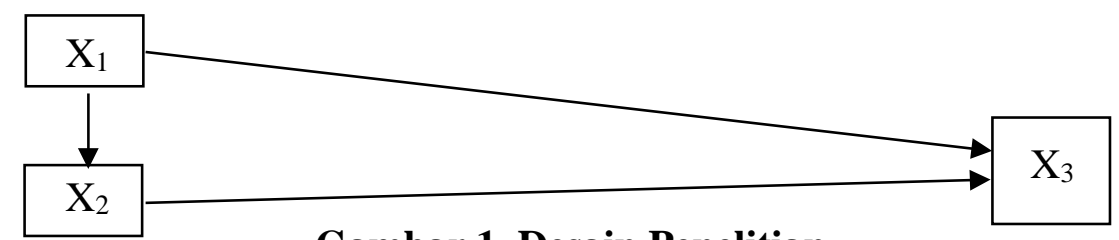

Gambar 1. Desain Penelitian

Keterangan :

$\mathrm{X}_{1}$ (variabel eksogen) : Perhatian Kepala Sekolah

$\mathrm{X}_{2}$ (variabel intervening) : Sikap Akhlakul Karimah Guru $\mathrm{X}_{3}$ (variabel endogen)

: Hasil Pendidikan Karakter Santri

Teknik sampling yang digunakan adalah propotional random sampling yang ditentukan menggunakan teknik Slovin dengan error sebesar 9\%, sehingga sampel terdiri dari 30 responden untuk uji coba dan sampel dalam penelitian terdiri dari 110 guru yang terdiri atas 59 guru Pondok Modern Darussalam Gontor Putra 1 dan 51 guru Pondok Modern Darussalam Gontor Putri 1.. Peneliti menyebarkan kuesioner melalui link google form untuk responden yang memiliki kriteria menjabat sebagai wali kelas atau asisten wali kelas 1-6 KMI di Pondok modern Darussalam Gontor Putra dan Putri ${ }^{1}$.

Ketiga variabel menggunakan model skala Likert dengan 5 penyajian alternatifjawaban. Variabel perhatian kepala sekolah didapat berdasarkan skor yang diperoleh melalui skala pengukuran yang dikembangkan oleh peneliti dengan mengadaptasi teori atensi Santrock (2014) yang dikombinasikan dengan tugas pokok kepala sekolah oleh Rusyan (2013) berdasarkan tiga dimensi yaitu pengelolaan, pengawasan dan tanggung jawab.

4Wawancara dengan wali murid Pondok Modern Darussalam Gontor, pada tanggal 12 Desember 2019

6 Mar'ati, R. 2014. Pesantren Sebagai Basis Pendidikan Karakter; Tinjauan Psikologis. Al-Murabbi : Jurnal Studi Kependidikan dan KeIslaman, 1(1), 1-15

7 M. Ihsan Dacholfany, op, cit., 
Pada awalnya skala ini berjumlah 24 item dengan 16 item favorable dan 8 item unfavorable. Namun setelah uji validitas, terdapat 5 item yang gugur sehingga tersisa 19item dengan alpha Cronbach sebesar 0.962. Variabel sikap akhlakul karimah gurudidapat berdasarkan skor yang diperoleh melalui skala pengukuran yang dikembangkan oleh peneliti dengan mengadaptasi teori akhlakul karimah Razak, dkk (2011) dan menyandingkannya dengan teori character strength and virtue Peterson \& Seligman (2004) berdasarkan tiga dimensi yaitu integritas, kemanusiaan dan kesederhanaan. Pada awalnya skala ini berjumlah 33 item dengan 22 item favorable dan 11 item unfavorable. Namun setelah uji validitas, terdapat 85 item yang gugur sehingga tersisa 25 item dengan alpha Cronbach sebesar 0.914. Variabel hasil pendidikan karakter santrididapat berdasarkan skor yang diperoleh melalui skala pengukuran yang dikembangkan oleh peneliti dengan mengadaptasi panca jiwa dan motto Pondok Modern Darussalam Gontor, berdasarkan dua dimensi yaitu panca jiwa dan motto pondok. Pada awalnya skala ini berjumlah 27 item dengan 18 item favorable dan 9 item unfavorable. Namun setelah uji validitas, terdapat 7 item yang gugur sehingga tersisa 20 item dengan alpha Cronbach sebesar 0.904 .

\section{HASIL PENELITIAN DAN PEMBAHASAN}

\section{Deskripsi Data}

\section{Deskripsi Data Hasil Pendidikan Karakter Santri}

Data hasil pendidikan karakter santri dalam penelitian ini diperoleh dari hasil pengisian kuesioner melalui media google form yang diberikan kepada wali kelas 16 KMI Pondok Modern Darussalam Gontor Putra dan Putri 1. Kuesioner yang digunakan dalam penelitian ini menggunakan skala Likert dengan lima pilihan jawaban dan berjumlah 20 butir, adapun hasil yang diperoleh dari pengisian kuesioner oleh walikelas dalam penelitian ini dapat dilihat pada tabel dan gambar dibawah ini.

Tabel 1. Deskripsi Data Hasil Pendidikan Karakter Santri

\begin{tabular}{|c|c|c|}
\hline \multicolumn{2}{|c|}{ Statistics } & Hasil Pendidikan Karakter Santri \\
\hline $\mathrm{N}$ & Valid & 110 \\
\hline & Missing & 0 \\
\hline & & 40.9091 \\
\hline & & 41.0000 \\
\hline & & 41.00 \\
\hline & & 4.64629 \\
\hline & & 21.588 \\
\hline & & 25.00 \\
\hline & & 29.00 \\
\hline & & 54.00 \\
\hline
\end{tabular}




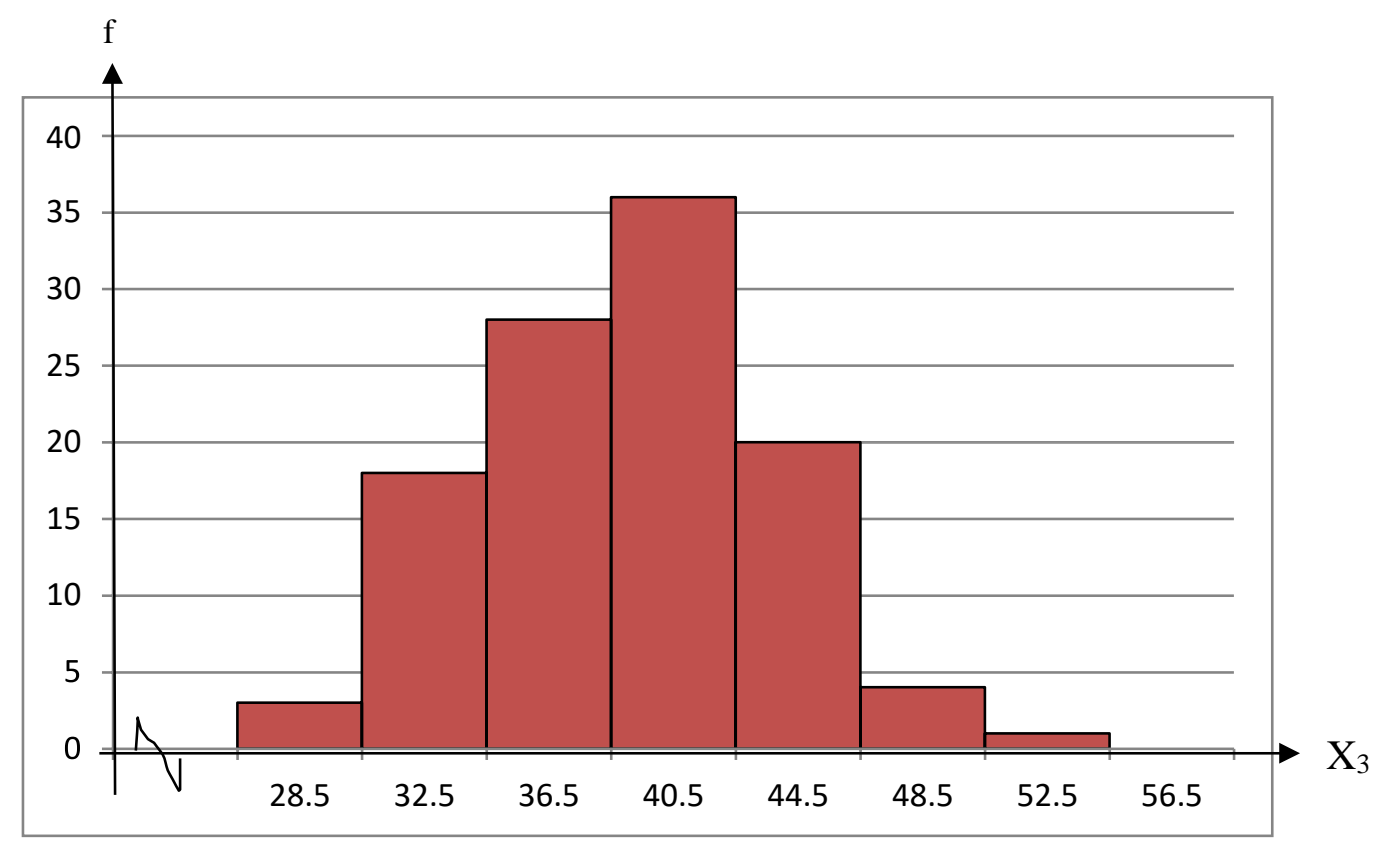

Gambar 2. Histogram Data Hasil Pendidikan Karakter

Berdasarkan output di atas menunjukkan jumlah responden $(\mathrm{N})$ sebanyak 110 responden. Pada data Hasil Pendidikan Karakter Santri (HPKS), diperoleh ratarata (mean) sebesar 40.9091, nilai tengah (median) pada skor 41, dengan skor terbanyak (modus) adalah 41. Standar deviasi dalam data ini adalah 4.64629 dengan varians sebesar 21.588. Jangkauan data (range) sebesar 25 dengan skor terkecil (minimum) adalah 29 dan skor terbesar (maksimum) adalah 54. Dari data di atas dapat diketahui pula bahwa data hasil pendidikan karakter santri yang didapat dari wali kelas sangat bervariasi dan berdistribusi normal.

\section{Deskripsi Data Perhatian Kepala Sekolah}

Data perhatian kepala sekolah dalam penelitian ini diperoleh dari hasil pengisian kuesioner melalui media google form yang diberikan kepada wali kelas 1-6 KMI Pondok Modern Darussalam Gontor Putra dan Putri 1. Kuesioner yang digunakan dalam penelitian ini menggunakan skala Likert dengan lima pilihan jawaban dan berjumlah 19 butir, adapun hasil yang diperoleh dari pengisian kuesioner oleh walikelas dalam penelitian ini dapat dilihat pada tabel dan gambar dibawah ini. 
Tabel 2. Deskripsi Data Perhatian Kepala Sekolah

\begin{tabular}{|llr|}
\multicolumn{2}{c|}{ Statistics } \\
\hline N & Valid & PKS \\
Mean & Missing & 110 \\
Median & & 0 \\
Mode & & 30.0818 \\
Std. Deviation & & 30.0000 \\
Variance & $25.00^{\mathrm{a}}$ \\
Range & & 5.29000 \\
Minimum & & 27.984 \\
Maximum & & 22.00 \\
& & 20.00 \\
\hline
\end{tabular}

Multiple modes exist. The smallest value is shown

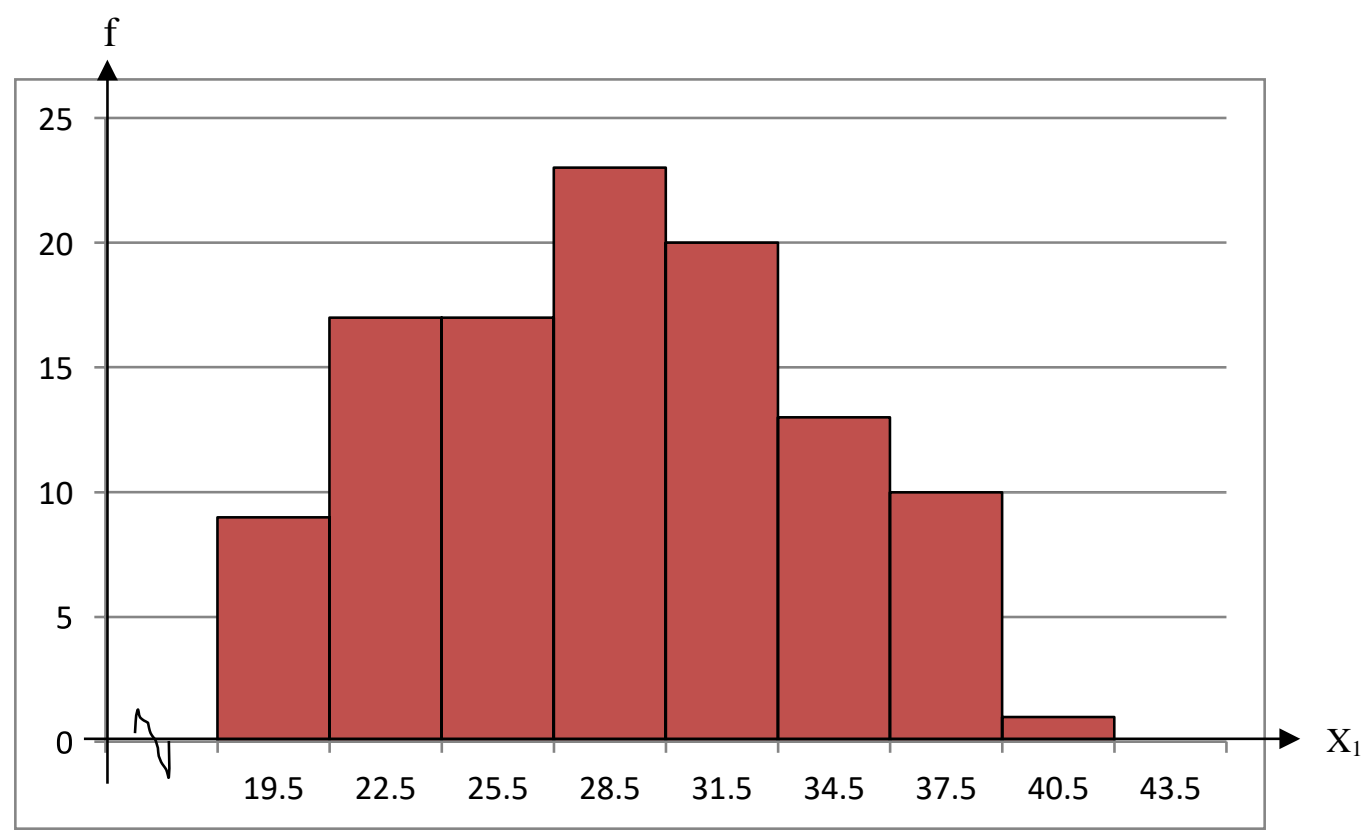

Gambar 3. Histogram Data Perhatian Kepala Sekolah

Berdasarkan output di atas menunjukkan jumlah responden (N) sebanyak 110 responden. Pada data Perhatian Kepala Sekolah (PKS), diperoleh rata-rata (mean) sebesar 30.0818, nilai tengah (median) pada skor 30, dengan skor terbanyak (modus) adalah 25. Standar deviasi dalam data ini adalah 5.29 dengan varians sebesar 27.984. Jangkauan data (range) sebesar 22 dengan skor terkecil (minimum) adalah 20 dan skor terbesar (maksimum) adalah 42. Dari data di atas dapat diketahui pula bahwa data Perhatian Kepala Sekolah yang didapat dari wali kelas sangat bervariasi danberdistribusi normal. 


\section{Deskripsi Data Sikap Akhlakul Karimah Guru}

Data sikap akhlakul karimah guru dalam penelitian ini diperoleh dari hasil pengisian kuesioner melalui media google form yang diberikan kepada wali kelas 16 KMI Pondok Modern Darussalam Gontor Putra dan Putri 1. Kuesioner yang digunakan dalam penelitian ini menggunakan skala Likert dengan lima pilihan jawaban dan berjumlah 25 butir, adapun hasil yang diperoleh dari pengisian kuesioner oleh walikelas dalam penelitian ini dapat dilihat pada tabel dan gambar dibawah ini.

Tabel 3. Deskripsi Data Sikap Akhlakul Karimah Guru

\begin{tabular}{|c|c|c|}
\hline \multicolumn{3}{|c|}{ Statistics } \\
\hline & & SAKG \\
\hline \multirow[t]{2}{*}{$\mathrm{N}$} & Valid & 110 \\
\hline & Missing & 0 \\
\hline \multicolumn{2}{|c|}{ Mean } & 58.7182 \\
\hline \multicolumn{2}{|c|}{ Median } & 59.0000 \\
\hline \multicolumn{2}{|c|}{ Mode } & 59.00 \\
\hline \multicolumn{2}{|c|}{ Std. Deviation } & 5.98183 \\
\hline \multicolumn{2}{|c|}{ Variance } & 35.782 \\
\hline \multicolumn{2}{|c|}{ Range } & 32.00 \\
\hline \multicolumn{2}{|c|}{ Minimum } & 38.00 \\
\hline \multicolumn{2}{|c|}{ Maximum } & 70.00 \\
\hline
\end{tabular}

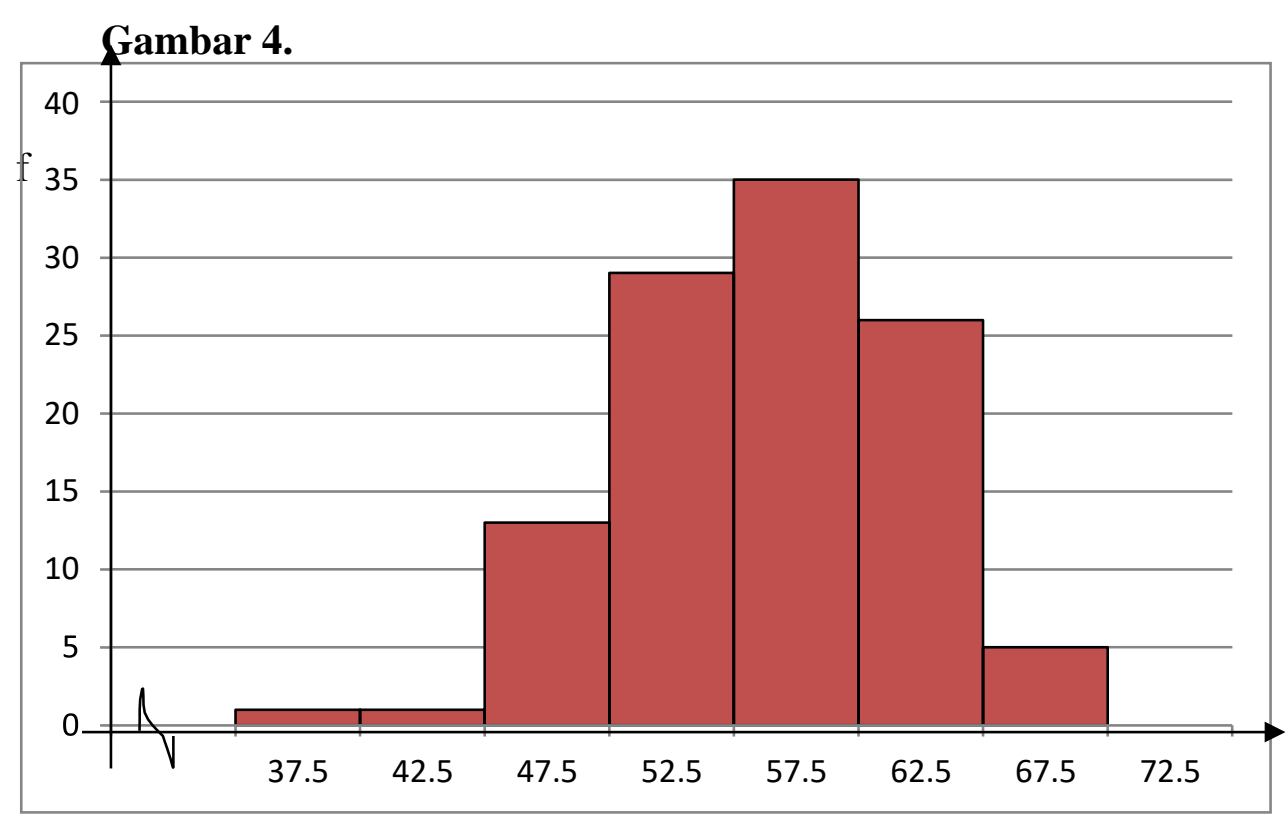

Gambar 4. Histogram Data Sikap Akhlakul Karimah Guru 
Berdasarkan output di atas menunjukkan jumlah responden (N) sebanyak 110 responden. Pada data Sikap Akhlakul KArimah Guru (SAKG), diperoleh ratarata (mean) sebesar 58.7182, nilai tengah (median) pada skor 59, dengan skor terbanyak (modus) adalah 59. Standar deviasi dalam data ini adalah 5.98183 dengan varians sebesar 35.782. Jangkauan data (range) sebesar 32 dengan skor terkecil (minimum) adalah 38 dan skor terbesar (maksimum) adalah 70. Dari data di atas dapat diketahui pula bahwa data sikap akhlakul karimah guru sangat bervariasi dan berdistribusi normal.

\section{Uji Persyaratan Analisis}

\section{Hasil Uji Normalitas Masing-masing Variabel}

Sebagai persyaratan untuk pengujian hipotesis pada statistika inferensial, maka harus dilakukan pengujian asumsi distribusi normal atau uji normalitas galat taksiran regresi. Hal ini bertujuan untuk mengetahui apakah sampel berasal dari populasi yang berdistribusi normal atau tidak. Pada penelitian ini, uji normalitas masing-masing variabel menggunakan uji normalitas dengan uji Lilieforse yang dibantu menggunakan SPSS versi 22.00. Uji normalitas masing-masing variabel pada penelitian ini digunakan untuk menguji variabel Hasil Pendidikan Karakter Santri (HPKS), Perhatian Kepala Sekolah (PKS) dan Sikap Akhlakul Karimah Guru (SAKG). Lebih jelasnya dapat dilihatpada tabel 5.

Tabel 5. Hasil Uji Normalitas Masing-masing Variabel One-Sample Kolmogorov-Smirnov Test

\begin{tabular}{llrrr}
\hline & & HPKS & \multicolumn{1}{c}{ PKS } & \multicolumn{1}{c}{ SAKG } \\
\hline $\mathrm{N}$ & & 110 & 110 & 110 \\
\hline Normal Parameters $^{\mathrm{a}, \mathrm{b}}$ & Mean & 40.9091 & 30.0818 & 58.7182 \\
\cline { 2 - 5 } & Std. Deviation & 4.64629 & 5.29000 & 5.98183 \\
\hline Most Extreme & Absolute & .074 & .071 & .073
\end{tabular}




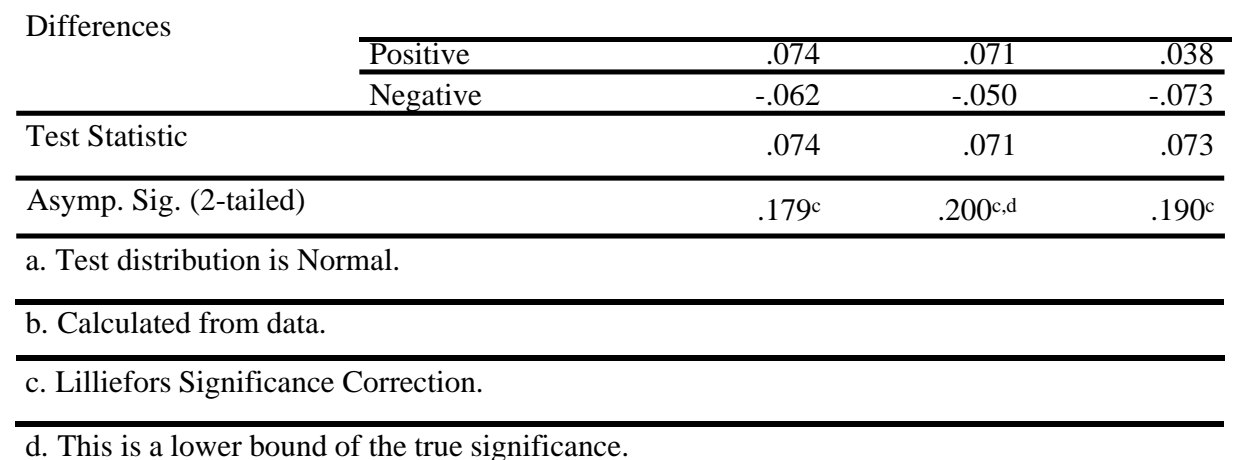

Hipotesis yang akan diuji pada kasus ini ${ }^{8}$ adalah :

$\mathrm{H}_{0}$ : Distribusi populasi normal, jika probabilitas $>0.05, \mathrm{H}_{0} \quad$ diterima

$\mathrm{H}_{1}$ : Distribusi populasi tidak normal, jika probabilitas $\leq 0.05, \mathrm{H}_{0} \quad$ ditolak

Dari output di atas, pada variabel Hasil Pendidikan Karakter Santri (HPKS) diperoleh test statistic sebesar 0.074, dengan nilai probabilitas ( $\mathrm{p}$-value) $=0.179>$ 0.05 atau $\mathrm{H}_{0}$ diterima. Dengan demikian, data Hasil Pendidikan Karakter Santri (HPKS) berdistribusi normal. Pada variabel Perhatian Kepala Sekolah (PKS) diperoleh teststatistic sebesar 0.071, dengan nilai probabilitas (p-value) $=0.200>$ 0.05 atau $\mathrm{H}_{0}$ diterima. Dengan demikian, data Perhatian Kepala Sekolah (PKS) berdistribusi normal. Pada variabel Sikap Akhlakul Karimah Guru (SAKG) diperoleh test statistic sebesar 0.073, dengan nilai probabilitas (p-value) $=0.190>$ 0.05 atau $\mathrm{H}_{0}$ diterima. Dengan demikian, data Sikap Akhlakul Karimah Guru (SAKG) berdistribusi normal.

\section{Uji Normalitas Galat Taksiran Regresi $X_{3}$ atas $X_{1}$}

Pada penelitian ini, uji normalitas galat taksiran regresi variabel hasil pendidikan karakter santri $\left(\mathrm{X}_{3}\right)$ atas variabel perhatian kepala sekolah $\left(\mathbf{X}_{1}\right)$ menggunakan uji normalitas dengan uji Lilieforse yang dibantumenggunakan Ms. Excel dengan persamaan $\mathrm{X}_{3}=0.0012+1.360 \mathrm{X}_{1}$, yang mana diperoleh $\mathrm{L}_{\mathrm{hitung}}=$ $0.057<\mathrm{L}_{\text {tabel }}=0.084(\alpha=0.05$ dan $n=110)$ yang $\underset{\wedge}{\operatorname{artinya}}$ data galat taksiran berasal dari populasi berdistribusi normal.

\section{Uji Normalitas Galat Taksiran Regresi $\mathrm{X}_{3}$ atas $\mathbf{X}_{2}$}

Uji normalitas galat taksiran regresi variabel hasil pendidikan karaktersantri

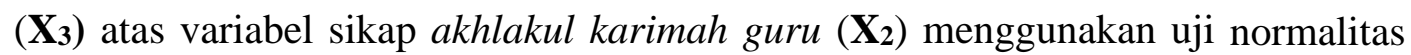
dengan uji Lilieforse yang dibantu menggunakan Ms. Excel dengan persamaan $\mathrm{X}_{3}$ 
$=-0.018+0.697 \mathrm{X}_{2}$, yang mana diperoleh $\mathrm{L}_{\mathrm{hitung}}=0.076<\mathrm{L}_{\text {tabel }}=0.084(\alpha=$

0.05 dan $n=110$ ) yang artinya data galat taksiran berasal dari populasi berdistribusi normal.

\section{Uji Normalitas Galat Taksiran Regresi $\mathbf{X}_{2}$ atas $\mathbf{X}_{1}$}

Uji normalitas galat taksiran regresi variabel sikap akhlakul karimah guru $\left(\mathrm{X}_{2}\right)$ atas variabel perhatiankepala sekolah $\left(\mathrm{X}_{1}\right)$ menggunakan ujinormalitas dengan uji Lilieforse yang dibantu menggunakan Ms. Excel dengan persamaan $\mathrm{X}_{2}=0.064$ $+1.952 \mathrm{X}_{1}$, yang mana diperoleh $\mathrm{L}_{\text {hitung }}=0.074<\mathrm{L}_{\text {tabel }}=0.084(\alpha=0.05$ dan $\mathrm{n}$ $=110$ ) yang artinya data galat taksiran berasal dari populasi berdistribusi normal.

\section{Pengujian Hipotesis}

\section{Hubungan antara X1 dan X3}

Persamaan Regresi

Tabel 6. Persamaan regresi $X_{1}$ terhadap $X_{3}$ Coefficients $^{\mathbf{a}}$

\begin{tabular}{|c|c|c|c|c|c|c|}
\hline \multirow{2}{*}{\multicolumn{2}{|c|}{ Model }} & \multicolumn{2}{|c|}{ Unstandardized Coefficients } & \multirow{2}{*}{$\begin{array}{c}\begin{array}{r}\text { Standardized } \\
\text { Coefficients }\end{array} \\
\text { Beta }\end{array}$} & \multirow[b]{2}{*}{$\mathrm{T}$} & \multirow[b]{2}{*}{ Sig. } \\
\hline & & $\mathrm{B}$ & Std. Error & & & \\
\hline & (Constant) & 31.226 & 2.401 & & 13.003 & .000 \\
\hline & PKS & .322 & .079 & .366 & 4.093 & .000 \\
\hline
\end{tabular}

Dependent Variable: HPKS

$\hat{\mathrm{X}}_{3}=\mathrm{a}+\mathrm{b} \mathrm{X}_{1} \quad \mathrm{X}_{3}=31.226+0.322 \mathrm{X}_{1}$

Persamaan regresi di atas menggambarkan bahwa setiap kenaikan 1 poin pada $\mathrm{X}_{1}$ akan diikuti oleh kenaikan $\mathrm{X}_{3}$ sebesar 0.322 pada kondisi awal 31.226. Tabel di atasjuga menunjukkan bahwa $\mathrm{r}_{13}=0.366$ dengan nilai $\mathrm{t}=4.093$ dan $\mathrm{p}$-value $=0.000<0.05$ atau $\mathrm{H}_{0}$ ditolak, yang bermakna terdapat hubungan positif antara perhatian kepala sekolah dengan hasil pendidikan karakter santri.

\section{Uji Signifikansi Koefisien Regresi}

Tabel 7. Uji Signifikansi Koefisien Regresi $X_{1}$ terhadap $X_{3}$ ANOVA ${ }^{a}$

\begin{tabular}{|c|c|c|c|c|c|}
\hline Model & $\begin{array}{l}\text { Sum of } \\
\text { Squares }\end{array}$ & Df & $\begin{array}{c}\text { Mean } \\
\text { Square }\end{array}$ & $\mathrm{F}$ & Sig. \\
\hline $1 \quad$ Regression & 316.027 & 1 & 316.027 & 16.755 & $.000^{\mathrm{b}}$ \\
\hline Residual & 2037.063 & 108 & 18.862 & & \\
\hline Total & 2353.091 & 109 & & & \\
\hline
\end{tabular}


Berdasarkan tabel di atas dapat dilihat jumlah kuadrat dan derajat kebebasan sumber varians yaitu, JK (reg) $=316.027$ dengan $\mathrm{db}=1, \mathrm{JK}(\mathrm{S})=2037.063$ dengan $\mathrm{db}=108$ dan JK $(\mathrm{TR})=2353.091$ dengan $\mathrm{db}=109$. Skor statistik $\mathrm{F}=16.755$, dan $\mathrm{p}$-value $=0.000<$ 0.05 berarti $\mathrm{H}_{0}$ ditolak, sehingga terdapat hubungan positif yang signifikanantara perhatian kepala sekolah dengan hasil pendidikan karakter santri.

\section{Uji Linearitas Regresi}

Tabel 8. Uji Signifikansi Linearitas Regresi $X_{1}$ terhadap $X_{3}$

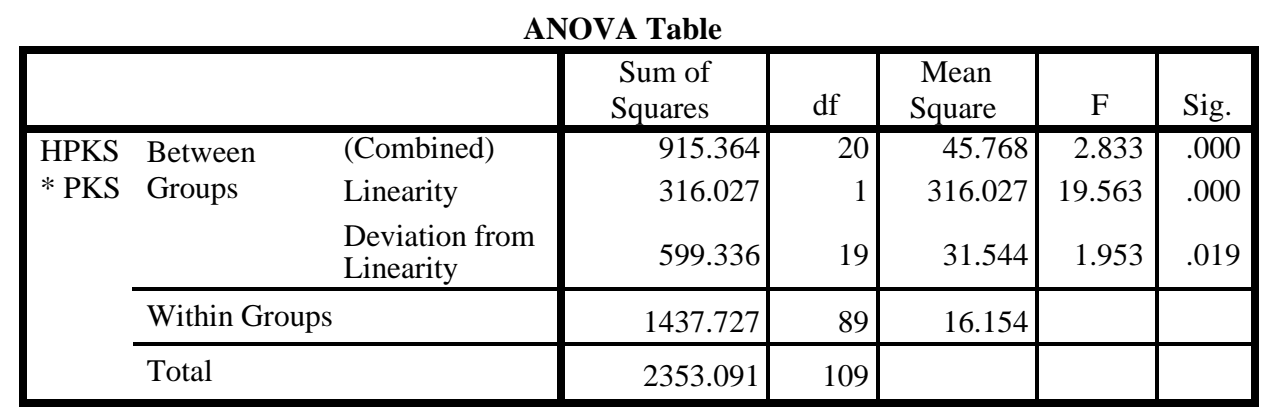

Tabel di atas menyajikan data berupa JK $(\mathrm{reg})=316.027$ dengan $\mathrm{db}=1$, JK $(\mathrm{TC})=$ 599.336 dengan $\mathrm{db}=19, \mathrm{JK}(\mathrm{G})=1437.727$ dengan $\mathrm{db}=89$ dan $\mathrm{JK}(\mathrm{TR})=2353.091$ dengan $\mathrm{db}=109$. Skor $\mathrm{F}_{\text {hitung }}=1.953>\mathrm{F}_{\text {tabel }}=1.70(\alpha=0.05)$ dengan $\mathrm{p}$-value $=0.019<0.05$ yang berarti $\mathrm{H}_{0}$ diterima, sehingga dapat disimpulkan bahwa hubungan antaraperhatian kepala sekolah dengan hasil pendidikan karakter santri tidak linear.

\section{Hubungan antara X2 dan X3}

\section{Persamaan Regresi}

Tabel 9. Persamaan regresi $\mathrm{X}_{2}$ terhadap $\mathrm{X}_{3}$

Coefficients $^{\mathrm{a}}$

\begin{tabular}{|c|c|c|c|c|c|c|}
\hline \multirow{2}{*}{\multicolumn{2}{|c|}{ Model }} & \multicolumn{2}{|c|}{$\begin{array}{c}\text { Unstandardized } \\
\text { Coefficients }\end{array}$} & \multirow{2}{*}{$\begin{array}{c}\begin{array}{r}\text { Standardized } \\
\text { Coefficients }\end{array} \\
\text { Beta }\end{array}$} & \multirow[b]{2}{*}{$\mathrm{T}$} & \multirow[b]{2}{*}{ Sig. } \\
\hline & & $\mathrm{B}$ & Std. Error & & & \\
\hline \multirow[t]{2}{*}{1} & (Constant) & 22.931 & 4.054 & & 5.656 & .000 \\
\hline & SAKG & .306 & .069 & .394 & 4.457 & .000 \\
\hline
\end{tabular}

a. Dependent Variable: HPKS

$$
\mathrm{X}_{3}=\mathrm{a}_{2}+\mathrm{b}_{2} \mathrm{X}_{2} \longrightarrow \mathrm{X}_{3}=22.931+0.306 \mathrm{X}_{2}
$$

Persamaan regresi di atas menggambarkan bahwa setiap kenaikan 1 poin pada $X_{2}$ akan diikuti oleh kenaikan $\mathrm{X}_{3}$ sebesar 0.306 pada kondisi awal 22.931. Tabel di atas juga menunjukkan bahwa $\mathrm{r}_{23}=0.394$ dengan nilai $\mathrm{t}=4.457$ dan $\mathrm{p}$-value $=0.000<0.05$ atau $\mathrm{H}_{0}$ ditolak, yang bermakna terdapat hubungan positif antara sikap akhlakul karimahguru dengan hasil pendidikan karakter santri. 


\section{Uji Signifikansi Koefisien Regresi}

Tabel 10. Uji Signifikansi Koefisien Regresi $X_{2}$ terhadap $X_{3}$

\begin{tabular}{|ll|r|r|r|r|r|}
\hline \multicolumn{2}{|l|}{ Model } & \multicolumn{1}{|c|}{$\begin{array}{c}\text { Sum of } \\
\text { Squares }\end{array}$} & df & $\begin{array}{c}\text { Mean } \\
\text { Square }\end{array}$ & \multicolumn{1}{c|}{ F } & Sig. \\
\hline 1 & Regression & 365.634 & 1 & 365.634 & 19.869 & $.000^{\mathrm{b}}$ \\
& Residual & 1987.457 & 108 & 18.402 & & \\
& Total & 2353.091 & 109 & & & \\
\hline
\end{tabular}

a. Dependent Variable: HPKS

b. Predictors: (Constant), SAKG

Berdasarkan tabel di atas dapat dilihat jumlah kuadrat dan derajat kebebasan sumber varians yaitu, JK (reg) = 365.634 dengan $\mathrm{db}=1, \mathrm{JK}(\mathrm{S})=1987.457$ dengan $\mathrm{db}=108 \mathrm{dan} \mathrm{JK}$ $(\mathrm{TR})=2353.091$ dengan $\mathrm{db}=109$. Skor statistik $\mathrm{F}=19.869$, dan $\mathrm{p}$-value $=0.000<0.05$ berarti $\mathrm{H}_{0}$ ditolak, sehingga terdapat hubungan positif yang signifikanantara sikap akhlakul karimah guru dengan hasil pendidikan karakter santri.

\section{Uji Linearitas Regresi}

Tabel 11. Uji Signifikansi Linearitas Regresi $X_{2}$ terhadap $X_{3}$

ANOVA Table

\begin{tabular}{|lll|r|r|r|r|r|}
\hline & & \multicolumn{1}{c|}{$\begin{array}{c}\text { Sum of } \\
\text { Squares }\end{array}$} & df & \multicolumn{1}{c|}{$\begin{array}{c}\text { Mean } \\
\text { Square }\end{array}$} & \multicolumn{1}{c|}{ F } & Sig. \\
\hline HPKS * & Between & (Combined) & 841.538 & 23 & 36.589 & 2.082 & .008 \\
SAKG & Groups & Linearity & 365.634 & 1 & 365.634 & 20.803 & .000 \\
& & Deviation from & 475.903 & 22 & 21.632 & 1.231 & .245 \\
\cline { 2 - 8 } & & Linearity & 1511.553 & 86 & 17.576 & & \\
\cline { 2 - 9 } & & 2353.091 & 109 & & & \\
\hline
\end{tabular}

Tabel di at as menyajikan data berupa JK (reg) $=365.634$ dengan $\mathrm{db}=1, \mathrm{JK}(\mathrm{TC})=$ 475.903 dengan $\mathrm{db}=22$, $\mathrm{JK}(\mathrm{G})=1511.553$ dengan $\mathrm{db}=86$ dan $\mathrm{JK}(\mathrm{TR})=2353.091$ dengan $\mathrm{db}=109$. Skor $\mathrm{F}_{\text {hitung }}=1.231<\mathrm{F}_{\text {tabel }}=1.70(\alpha=0.05)$ dengan $\mathrm{p}$-value $=0.245>0.05$ yang berarti $\mathrm{H}_{0}$ ditolak, sehingga terdapat hubungan linear antara sikap akhlakulkarimah guru dengan hasil pendidikan karakter santri. 


\section{Hubungan antara X1 dan X2}

\section{Persamaan Regresi}

Tabel 12. Persamaan regresi $X_{1}$ terhadap $X_{2}$

Coefficients $^{\mathbf{a}}$

\begin{tabular}{|c|c|c|c|c|c|}
\hline \multirow[b]{2}{*}{ Model } & \multicolumn{2}{|c|}{$\begin{array}{c}\text { Unstandardized } \\
\text { Coefficients }\end{array}$} & \multirow{2}{*}{$\begin{array}{c}\begin{array}{r}\text { Standardized } \\
\text { Coefficients }\end{array} \\
\text { Beta }\end{array}$} & \multirow[b]{2}{*}{$\mathrm{t}$} & \multirow[b]{2}{*}{ Sig. } \\
\hline & $\mathrm{B}$ & Std. Error & & & \\
\hline $1 \quad$ (Constant) & 44.265 & 3.008 & & 14.715 & .000 \\
\hline PKS & .480 & .098 & $\mathrm{r}_{12}=\mathrm{p}_{21}=.425$ & 4.878 & .000 \\
\hline
\end{tabular}

Persamaan regresi di atas menggambarkan bahwa setiap kenaikan 1 poin pada $\mathrm{X}_{1}$ akan diikuti oleh kenaikan $\mathrm{X}_{2}$ sebesar 0.480 pada kondisi awal 44.265. Tabel di atas juga menunjukkan bahwa $\mathrm{r}_{12}=0.425$ dengan nilai $\mathrm{t}=4.093$ dan $\mathrm{p}$-value $=0.000<0.05$ atau $\mathrm{H}_{0}$ ditolak, yang bermakna terdapat hubungan positif antara perhatian kepala sekolah dengan sikap akhlakul karimah guru. Dalam hal ini $\mathrm{r}_{12}$ juga $\mathrm{p}_{21}$, sehinggaterdapat pengaruh langsung positif perhatian kepala sekolah terhadap sikap akhlakul karimah guru.

\section{Uji Signifikansi Koefisien Regresi}

Tabel 13. Uji Signifikansi Koefisien Regresi $X_{1}$ terhadap $X_{2}$

$$
\text { ANOVA }^{\mathrm{a}}
$$

\begin{tabular}{|c|c|c|c|c|c|c|}
\hline \multicolumn{2}{|c|}{ Model } & Sum of & $\mathrm{df}$ & Mean & $\mathrm{F}$ & Sig. \\
\hline \multirow[t]{3}{*}{1} & $\begin{array}{l}\text { Regres } \\
\text { sion }\end{array}$ & 704.135 & 1 & 704.135 & $\begin{array}{r}23.7 \\
93\end{array}$ & .000 \\
\hline & $\begin{array}{l}\text { Residu } \\
\text { al }\end{array}$ & $\begin{array}{r}3196.12 \\
9\end{array}$ & 108 & 29.594 & & \\
\hline & Total & $\begin{array}{r}3900.26 \\
4\end{array}$ & 109 & & & \\
\hline
\end{tabular}

a. Dependent Variable: SAKG

b. Predictors: (Constant), PKS

Berdasarkan tabel di atas dapat dilihat jumlah kuadrat dan derajat kebebasan sumber varians yaitu, JK (reg) = 704.135 dengan $\mathrm{db}=1, \mathrm{JK}(\mathrm{S})=3196.129$ dengan $\mathrm{db}=108 \mathrm{dan} \mathrm{JK}$ $(\mathrm{TR})=3900.264$ dengan $\mathrm{db}=109$. Skor statistik $\mathrm{F}=23.793$, dan $\mathrm{p}$-value $=0.000<0.05$ berarti $\mathrm{H}_{0}$ ditolak, sehingga terdapat hubungan positif yang signifikan antara perhatian kepala sekolah dengan sikap akhlakul karimah guru. 


\section{Uji Linearitas Regresi}

Tabel 14. Uji Signifikansi Linearitas Regresi $X_{1}$ terhadap $X_{2}$ ANOVA Table

\begin{tabular}{|c|c|c|c|c|c|c|c|}
\hline & & & $\begin{array}{l}\text { Sum of } \\
\text { Squares }\end{array}$ & Df & $\begin{array}{c}\text { Mean } \\
\text { Square }\end{array}$ & $\mathrm{F}$ & Sig. \\
\hline SAKG & Between & (Combined) & 1632.603 & 20 & 81.630 & 3.204 & .000 \\
\hline \multirow[t]{4}{*}{$*$ PKS } & Groups & Linearity & 704.135 & 1 & 704.135 & 27.636 & .000 \\
\hline & & $\begin{array}{l}\text { Deviation } \\
\text { from } \\
\text { Linearity }\end{array}$ & 928.469 & 19 & 48.867 & 1.918 & .022 \\
\hline & \multicolumn{2}{|c|}{ Within Groups } & 2267.660 & 89 & 25.479 & & \\
\hline & \multicolumn{2}{|l|}{ Total } & 3900.264 & 109 & & & \\
\hline
\end{tabular}

Tabel di atas menyajikan data berupa JK (reg) $=704.135$ dengan $\mathrm{db}=1, \mathrm{JK}(\mathrm{TC})=$ 928.469 dengan $\mathrm{db}=19, \mathrm{JK}(\mathrm{G})=2267.660$ dengan $\mathrm{db}=89$ dan JK $(\mathrm{TR})=3900.264$ dengan $\mathrm{db}=109$. Skor $\mathrm{F}_{\text {hitung }}=1.918>\mathrm{F}_{\text {tabel }}=1.70(\alpha=0.05)$ dengan $\mathrm{p}$-value $=0.022<0.05$ yang berarti $\mathrm{H}_{0}$ diterima, sehingga dapat disimpulkan bahwa hubungan antara perhatian kepala sekolah dengan sikap akhlakul karimah guru tidak linear.

\section{Hubungan antara X1 dan X2 dengan X3}

Tabel 15. Persamaan regresi $X_{1}$ dan $X_{2}$ terhadap $X_{3}$

Coefficients $^{\mathrm{a}}$

\begin{tabular}{|c|c|c|c|c|c|c|}
\hline \multirow{2}{*}{\multicolumn{2}{|c|}{ Model }} & \multicolumn{2}{|c|}{$\begin{array}{c}\text { Unstandardized } \\
\text { Coefficients }\end{array}$} & \multirow{2}{*}{$\begin{array}{c}\begin{array}{r}\text { Standardized } \\
\text { Coefficients }\end{array} \\
\text { Beta }\end{array}$} & \multirow[b]{2}{*}{$\mathrm{t}$} & \multirow[b]{2}{*}{ Sig. } \\
\hline & & $\mathrm{B}$ & Std. Error & & & \\
\hline \multirow[t]{3}{*}{1} & (Constant) & 21.221 & 4.011 & & 5.290 & .000 \\
\hline & PKS & .213 & .084 & .243 & 2.548 & .012 \\
\hline & SAKG & .226 & .074 & .291 & 3.054 & .003 \\
\hline
\end{tabular}

a. Dependent Variable: HPKS

$$
\hat{\mathrm{X}}_{3}=\mathrm{a}+\mathrm{b} \mathrm{X}_{1}+\mathrm{b} \mathrm{X}_{2} \longrightarrow \hat{\mathrm{X}}_{3}=21.221+0.213 \mathrm{X}_{1}+0.226 \mathrm{X}_{2}
$$

Persamaan regresi di atas menggambarkan bahwa setiap kenaikan 1 poin pada $X_{1}$ akan diikuti oleh kenaikan $\mathrm{X}_{3}$ sebesar 0.213 dan setiap kenaikan 1 poin pada $\mathrm{X}_{2}$ akan diikuti pula oleh kenaikan $\mathrm{X}_{3}$ sebesar 0.226 pada kondisi awal 21.221. Tabel di atas juga menunjukkan bahwa $\mathrm{p}_{31}=0.243$ dengan nilai $\mathrm{t}=4.093$ dan $\mathrm{p}$-value $=0.012<0.05$ atau $\mathrm{H}_{0}$ ditolak, yang bermakna perhatian kepala sekolah berpengaruh langsung positif terhadap hasil pendidikan karakter santri. $\mathrm{p}_{32}=0.291$ dengan nilai $\mathrm{t}=3.054$ dan $\mathrm{p}$-value $=0.003<0.05$ atau $\mathrm{H}_{0}$ ditolak, yang bermakna sikap akhlakul karimah guru berpengaruh langsung positif terhadap hasil pendidikan karakter santri. 
Tabel 16. Ringkasan hasil pengujian hipotesis dengan SPSS

\begin{tabular}{ccccc}
\hline $\begin{array}{c}\text { Pengaruh langsung } \\
\text { antar variabel }\end{array}$ & $\begin{array}{c}\text { Koefisien } \\
\text { Jalur }\left(\mathbf{P}_{\mathbf{i j}}\right)\end{array}$ & $\mathbf{t}_{\text {hitung }}$ & p-value & simpulan \\
\hline $\begin{array}{c}\mathbf{X}_{\mathbf{1}} \text { terhadap } \mathbf{X}_{\mathbf{3}} \\
\left(\mathbf{p}_{\mathbf{3 1}}\right)\end{array}$ & 0.243 & 2.548 & 0.012 & Sig \\
\hline $\begin{array}{c}\mathbf{X}_{\mathbf{2}} \text { terhadap } \mathbf{X}_{\mathbf{3}} \\
\left(\mathbf{p}_{\mathbf{3 2}}\right)\end{array}$ & 0.291 & 3.054 & 0.003 & Sig \\
\hline $\begin{array}{c}\mathbf{X}_{\mathbf{1}} \text { terhadap } \mathbf{X}_{\mathbf{2}} \\
\left(\mathbf{p}_{\mathbf{2 1}}\right)\end{array}$ & 0.425 & 4.878 & 0.000 & Sig \\
\hline
\end{tabular}

Berdasarkan ringkasan hasil analisis diatas dapat diperolehpengaruh langsung, tak langsung dan total sebagai berikut :

\section{Pengaruh langsung}

Pengaruh variabel $X_{1}, X_{2}$ terhadap $X_{3}$ disebut sebagai pengaruhlangsung, yang bila disajikan secara sederhana :

- Pengaruh $\mathrm{X}_{1}$ terhadap $\mathrm{X}_{2}\left(\mathrm{p}_{21}\right)=0.425$

- Pengaruh $X_{1}$ terhadap $X_{3}\left(p_{31}\right)=0.243$

- Pengaruh $X_{2}$ terhadap $X_{3}\left(p_{32}\right)=0.291$

\section{Pengaruh tak langsung}

Pengaruh tak langsung $X_{1}$ terhadap $X_{3}$ melalui $X_{2}$ adalah hasilkali koefisien jalur $\mathrm{p}_{21}$ dan $\mathrm{p}_{32}=\mathrm{p}_{21} \times \mathrm{p}_{32}=0.425 \times 0.291=0.124$.

\section{Pengaruh total}

Jumlah antara pengaruh langsung dan pengaruh tak langsung adalah pengaruh total $\mathrm{X}_{2}$ terhadap $\mathrm{X}_{3}=\mathrm{p}_{31}+\left(\mathrm{p}_{21}\right)\left(\mathrm{p}_{32}\right)=0.243+0.124=0.367$.

\section{HASIL DAN PEMBAHASAN}

Pada bagian ini akan dijabarkan pembahasan hasil penelitian yang diperoleh dari analisis deskriptif dan model analisis jalur mengenai pengaruh antara perhatian kepala sekolah dan sikap akhlakul karimah guru terhadap hasil pendidikan karakter santri.

Pada pengujian hipotesis penelitian menghasilkan bahwa perhatian kepala sekolah berpengaruh positif dan signifikan terhadap hasil pendidikan karakter santri, namun pengaruhnya tidak bersifat linear. Begitu pula perhatian kepala sekolah memberikan pengaruh positif dan signifikan terhadap sikap akhlakul karimah guru, namun pengaruhnya tidak bersifat linear. Hal ini menjelaskan bahwa setiap perubahan yang terjadi pada perhatian kepala sekolah tidak akan diikuti perubahan 
dengan besaran yang sejajar pada hasil pendidikan karakter santri dan sikap akhlakul karimah guru.

Berbeda dengan sikap akhlakul karimah guru yang berpengaruh positif dan signifikan terhadap hasil pendidikan karakter santri serta pengaruhnya bersifat linear. Guru memiliki standard sikap yang dikemas oleh peraturan sekolah, selain itu guru juga dituntut untuk memiliki sikap terpuji. Ketika kepala sekolah memberikan perhatian lebih kepada sikap guru, akan berpengaruh pada guru untuk bersikap akhlakul karimah. Namun, bukan berarti ketika kepala sekolah menurunkan tingkat perhatiannya kepada sikap guru, makaguru akan bersikap semena-mena. Begitu pula dengan santri, hasil pendidikan karakter santri tidak serta-merta karena kepala sekolah memberikan perhatian penuh disetiap waktunya. Meskipun adakalanya perhatian tersebut berkurang namun hasil pendidikan karakter masih melekat dalam diri santri.

Berbeda dengan guru yang merupakan panutan dan teladan bagi santrinya. Bagi seorang anak didik, sikap guru akan selalu dikenang dan menjadi contoh yang melekat dalam dirinya. Perubahan dalam sikap guru akan berpengaruh pula pada hasil pendidikan karakter santri, sekecil apapun perubahan tersebut.

Menjawab rumusan masalah pertama, secara langsung dapat diamati pada tabel 25 yang menunjukkan bahwa perhatian kepala sekolah berpengaruh langsung positif terhadap hasil pendidikan karakter santri sebesar $24.3 \%$ (0.243) dengan nilai signifikansi sebesar 0.012. Hal ini menjelaskan bahwa perhatian kepala sekolah secara langsung berperan penting dalam memaksimalkan hasil pendidikan karakter santri.

Pernyataan ini didukung oleh penelitian Wholstetter, et al 1997 yang menghasilkan temuan bahwa perhatian kepala sekolah yang tinggi terhadap pembinaan mutu, perilaku terpuji dan sikap responsif dalam menangani permasalahan yang ada di sekolah secara signifikan dapat menurunkan frekuensi perilaku tak terpuji siswa dan dapat meningkatkan kesejahteraan kehidupan sekolah. Maraknya perilaku tak terpuji siswa merupakan penyebab dari timbulnya pendidikan karakter pada tingkat satuan pendidikan. Perhatian kepala sekolah dalam penelitian ini mencakup pengelolaan, pengawasan dan tanggung jawab kepala sekolah terhadap masyarakat sekolah, salah satunya adalah pendidikan karakter santri dan sikap guru. Penelitian yang dilakukanoleh Diyanto, dkk 29018 menemukan hasil bahwa kepala sekolah berperan penting dalam merencanakan, melaksanakan, mengendalikan secara konsisten pembentukan karakter dalam pendidikan sekolah. Peran kepala sekolah sebagai edukator dalam implementasi pendidikan karakter ditunjukkan dengan melakukan program kegiatanpembiasaan, kegiatan belajar mengajar, pembinaan dan motivasi kepada guru, menjadi suri 
tauladan, dan memberikan pidato atau arahan tentang pendidikan karakter.

Rumusan masalah kedua, secara langsung dapat diamati pada tabel 25 yang menunjukkan bahwa sikap akhlakul karimah guru berpengaruh langsung positif terhadap hasil pendidikan karakter santri sebesar $29.1 \%(0.291)$ dengan nilai signifikansi sebesar 0.003 .

Bila dibandingkan, sikap akhlakul karimah guru memiliki pengaruh langsung sedikit lebih besar daripada perhatian kepala sekolah terhadap hasil pendidikan karakter santri, hal ini menjelaskan bahwa kepribadian guru terutama wali kelas merupakan teladan bagi santrinya, karena wali kelas lebih intens berinteraksi dengan anak didiknya, bahkan di Pondok Modern Darussalam Gontor wali kelas dianggap sebagai orang tua kedua bagi santrinya, karena santri-santri jauh dari orang tuanya sehingga segala sikap dan perilaku wali kelas menjadi teladan bagi santri- santrinya. Seperti yang dikemukakan oleh Ki Hajar Dewantara "ing ngarsa sung tuladha, ing madya mangun karsa, tut wuri handayani” yang berarti seorang guru harusmenjadi contoh dan teladan serta membangkitkan, menyemangati dan memberi motivasiuntuk anak didiknya. Guru hendaknya memberi contoh sehingga bisa dilihat langsung dan ditiru oleh siswa baik saat di dalam maupun di luar kelas. Pernyataan ini didukung oleh penelitian Busyaeri dan Muharom 2016 yang menemukan hasil bahwa sikap guru berpengaruh positif terhadap pengembangan karakter siswa sebesar $26.11 \%$,

Menjawab rumusan ketiga dapat dilihat pada tabel 22 yang menunjukkan bahwa perhatian kepala sekolah berpengaruh langsung positif terhadap hasil pendidikan karakter santri sebesar $42.5 \%$ (0.425) dengan nilai signifikansi sebesar 0.000. Hal ini menjelaskan bahwa perhatian kepala sekolah secara langsung berperan penting terhadapsikap akhlakul karimah guru. Pernyataan ini didukung oleh penelitian yang dilakukan oleh Diyanto dkk 2018 bahwa peran kepala sekolah sebagai edukator dalam implementasi pendidikan karakter ditunjukkan dengan melakukan program kegiatan pembiasaan, pembinaan dan motivasi kepada guru serta menjadi suri tauladan.

Bila dilihat pengaruhnya, perhatian kepala sekolah memiliki pengaruh cukup besar terhadap sikap akhlakul karimah guru. Sesuai dengan tugasnya, kepala sekolah bertugasuntuk memimpin sekolah agar berjalan dengan baik dan mencapai tujuan yang diharapkan, kepala sekolah harus profesional. Artinya, ia memiliki kemampuanmenjalankan berbagai aktivitas sekolah, bahkan bertanggung jawab penuh membinadan mengembangkan guru serta tenaga kependidikan lainnya untuk tercapainyatujuan pendidikan, yang mana salah satu tujuan pendidikan adalah mengembangkan karakter peserta didik dan melahirkan generasi yang cerdas 
berkarakter.

Aktivitas yang dilakukan kepala sekolah dalam mengatur dan mengurus koepegawaian di sekolah adalah menentukan, memilih, menetapkan, dan membimbing para guru serta staf lainnya di sekolah untuk melaksanakan tugas dan tanggung jawabnya dengan sebaik-baiknya. Membimbing guru untuk memiliki sikap terpuji dan sikap akhlakul karimah adalah salah satu tugas kepala sekolah. Hal inilah yang menjelaskan penelitian ini mengapa perhatian kepala sekolah memiliki pengaruh langsung positif lebih besar terhadap sikap akhlakul karimah guru. Kepala sekolah lah yang bertanggung jawab atas bagaimana guru-guru di sekolahnya bersikap, kepalasekolah pula yang memberi sangsi jika guru melanggar aturan. Sedangkan santri lebih mencontoh guru yang sering berinteraksi dengannya yaitu wali kelas. Kualitas guru dapat dikontrol secara langsung oleh kepala sekolah. Di Pondok Modern Darussalam Gontor, kepala sekolah mengevaluasi perilaku guru dengan mengadakan pertemuan mingguan yang disebut kamisan. Disini, kepala sekolah mereview kinerja guru, memberi hukuman bagi guru yang lalai dan memberi apresiasi bagi guru yang berprestasi dan disiplin.

\section{KESIMPULAN}

Berdasarkan hasil penelitian, apabila Pondok Modern Darussalam Gontor Se-JawaTimur ingin meningkatkan hasil pendidikan karakter santri, maka perlu memperhatikan unsur-unsur perhatian kepala sekolah dan sikap akhlakul karimah guru terlebih dahulu agar hasil pendidikan karakater santri maksimal sesuai dengan panca jiwa dan motto pondok.

Terutama bagi kepala sekolah, hendaknya lebih memperhatikan sikap akhlakul karimah guru agar menjadi suri tauladan bagi santri-santrinya. Dengan sikap akhlakul karimah guru memberikan pengaruh positif lebih besar daripada perhatian kepala sekolah langsung terhadap hasil pendidikan karakter santri. Namun, perhatian kepala sekolah ternyata memberikan pengaruh langsung positif terbesar terhadap sikap akhlakul karimah guru, sehingga bila ditelaah berdasarkan hasil penelitian ini hasil pendidikan karakter santri diawali dengan perhatian kepala sekolah kepada guru agar guru-guru mampu menerapkan sikap akhlakul karimah dan menjadi contoh terpuji bagi santri-santrinya. Jika guru-guru memiliki sikap akhlakul karimah maka murid akanmencontoh sehingga menghasilkan pendidikan karakter yang maksimal sesuai dengan panca jiwa dan motto pondok.

Adapun kekurangan dalam penelitian ini adalah Variabel yang mempengaruhi hasil pendidikan karakter santri dalam penelitian ini hanya perhatian kepala sekolah dansikap akhlakul karimah guru, sedangkan masih banyak variabelvariabel lain yang dapatmempengaruhi hasil pendidikan karakter santri. Penyebaran data menggunakankuesioner melalui google form sehingga dikhawatirkan jawaban

Vol. 3 No. 1 (2021) 
yang diisi oleh responden tidak benar-benar menunjukkan keadaan sebenarnya. Sampel dalam penelitian ini hanya berjumlah 110 responden, dikhawatirkan kurang mampu mengeneralisasi atau menggambarkan hasil pendidikan karakter santri yang sesungguhnya.

\section{DAFTAR PUSTAKA}

Ahmadi, Abu. 2009. Psikologi Sosial. Jakarta : Rineka Cipta.

Archianty, Puti, dkk. 2013. Dasar-Dasar Psikologi. Jakarta : Uhamka Press

AR Muhammad, dkk. 2020. "Character Education, Student Mental Revolution, and Industry 4.0 : The case of State Islamic Senior High Schools in Indonesia". In International International Conference on Social Sciece and Character Educations (ICoSSCE 2019) (pp.132-135). Atlantis Press

Asmani, Ma'ruf, Jamal. 2013. Buku Panduan Internalisasi Pendidikan Karakter di Sekolah. Yogyakarta : Diva Press.

Azwar dan Ananda. 2009. Psikologi Pendidikan. Jakarta : Bumi Aksara.

Busyaeri, A., \& Muharom, M. 2016. "Pengaruh Sikap Guru Terhadap Pengembangan Karakter (Peduli Sosial) Siswa di MI Madinatunnajah Kota Cirebon". Al Ibtida : Jurnal Pendidikan Guru MI, 2 (1).

Buyung, Ireine. (2019). "Murid Tusuk Guru hingga Tewas, Izin SMK Ichthus Manado Dicabut”. $\quad$ https://m.detik.com/news/berita/d-4762662/murid-tusuk-guru-hinggatewas-izin-smk-ichthus-manado-dicabut.

Dacholfany, M. Ihsan. 2014. "Character Education Learning From Gontor, Wafi Media Tama, Director General of Religious Affairs, 2009”, Encyclopedia of Islam in Indonesia

Diyanto, D., Yuliejantiningsih, Y., \& Murniati, N. A. N. 2018. "Peran Kepala Sekolah dalam Implementasi Pendidikan Karakter di SMP PGRI Purwareja Klampok Kabupaten Banjanegara”. Jurnal Manajemen Pendidikan (JMP), 7(3).

Djamarah, Bahri, Syaiful dan Zain, Aswan. 2010. Strategi Belajar Mengajar. Jakarta : Rineka Cipta.

Anone. 2006. Ensiklopedia Tematik Al Qur'an. Jakarta : Paramadina

Hasan, Basri. 2014. Kepemimpinan Kepala Sekolah. Bandung : Pustaka Setia.

Humaerah, dkk. 2020. Teacher's Roles on the Implementation of Character Educationin Elementary Schools. In International Conference on Social Sciece and Character Educations (ICoSSCE 2019) (pp.24-29). Atlantis Press

Iman, Sa'aduddin, Mukmin, Abdul. 2006. Meneladani Akhlak Nabi Membangun Kepribadian Muslin. Bandung : Rosda Karya.

Kadar, Yusuf, M. 2013. Tafsir Tarbawi : Pesan-pesan Al Qur'an tentang Pendidikan. Jakarta : Amzah.

Kadir. 2018. Statistika Terapan Konsep, Contoh dan Analisis Data dengan Program SPSS/Lisrel dalam Penelitian. Depok : Rajawali Press.

Anone. 2017. "Infografis Penguatan Pendidikan Karakter". https://cerdasberkarakter.kemdikbud.go.id 
Kesuma, Dharma. Dkk. 2013. Pendidikan Karakter Kajian Teori dan Praktik di

Sekolah. . Bandung : Rosda Karya.

Anone. 2019. Jumlah Siswa/siwi dan Guru KMI Pondok Modern Darussalam

Gontor Seluruh Kampus semester Kedua Tahun Ajaran 1440-1441 H.

Ponorogo : Kulliyatul Mu'allimin Al Islamiyah.

Latief, Madjid, Abdul. 2017. Manajemen Pendidikan. Jakarta : Uhamka Press

Madjid Nurcholis. 1987. "Keharusan Pembaruan Pemikiran Islam dan Masalah Integrasi

Umat". Islam : Kemodernan dan KeIndonesiaan, 204-14

Mar'ati, R. 2014. "Pesantren Sebagai Basis Pendidikan Karakter; Tinjauan Psikologis". Al-

Murabbi : Jurnal Studi Kependidikan dan KeIslaman, 1(1), 1-15

Muhaimin. 2014. Pengembangan Kurikulum Pendidikan Agama Islam di Sekolah Madrasah dan Perguruan Tinggi. Depok : Rajagrafindo Persada.

Mukminin, A. 2014. "Strategi Pembentukan Karakter Peduli Lingkungan di Sekolah

Adiwiyata Mandiri”. Ta'dib : Journal of Islamic Education (Jurnal

Pendidikan Islam). 19(02), 227-252.

Mulyasa. 2016. Manajemen Pendidikan Karakter. Jakarta : Bumi Aksara.

Murwani, Santosa. Statistika Terapan Teknik Analisis Data. Jakarta : Sekolah

Pascasarjana Uhamka.

Peterson, Christoper and Seligman, Martin. 2004. Character Strenghts and Virtues. Oxford : American Psychological Association and oxford university press.

Anone. 2017. Warta Dunia. Ponorogo : Darussalam Press.

Anone. "Motto Pondok Modern Darussalam Gontor".

Availabel at www.gontor.ac.id/motto diakses pada 03 Februari 2020

Anone. "Panca Jiwa Pondok Modern Darussalam

Gontor". Availabel atwww.gontor.ac.id/pancajiwa

Priansa, Juni, Donni dan Somad, Rismi. 2014. Manajemen Supervisi Dan

Kepemimpinan Kepala Sekolah Bandung; : Alfabeta

Razak. Dkk. 2011. Pendidikan Agama. Jakarta : Uhamka Press.

Anone. Peraturan Presiden Republik Indonesia Nomor 87 Tahun 2017 tentang Penguatan Pendidikan Karakter Pasal 1 Butir.

Anone. Peraturan Presiden Republik Indonesia Nomor 87 Tahun 2017 tentang Penguatan Pendidikan Karakter Pasal 6 Butir 3, 4, 5.

Rusyan, Tabrani. 2013. Profesionalisme Kepala Sekolah, Jakarta: PT. Pustaka Dinamika.

Ryan, T. 2013. Sample Size determination and Power desain. New York : John Wileyand Sons.

Sahroji, Ahmad. 2017. "Kapolri Nilai Sifat dan Karakter Din Syamsuddin Patut jadi Contoh dan Teladan Semua Orang”. https://www.google.com/amp/s/nasional.okezone.com/amp/2017/11/20/337/ $\underline{1817}$ 367/kapolri-nilai-sifat-din-syamsuddin-patut-jadi-contoh-dan-teladansemua- orang. Diakses pada 03 Februari 2020

Samani, Muchlas. dan Haryanto. 2017. Konsep dan Model Pendidikan 
Karakter. Bandung : Rosda Karya.

Santrock, Jhon, W. 2014. Psikologi Pendidikan. Jakarta : Salemba Humanika. Sastroasmoro, S. Dan Ismail, S. 2008. Dasar-dasar Metodologi Penelitian Klinis Edisi III. Jakarta : CV Agung Seto.

Murwani, Santosa dkk. 2013. Pedoman Penulisan Tesis dan Disertasi. Jakarta : Uhamka Press.

Slameto. 2013. Belajar dan Faktor-faktor yang Mempengaruhinya. Jakarta : RinekaCipta.

Sobry, Sutikno. 2012. Manajemen Pendidikan Langkah Praktis Mewujudkan LembagaPendidikan yang Unggul. Lombok : Holistika.

Sugiono. 2017. Metode Penelitian Kuantitatif, Kualitatif dan R\&D. Bandung : Alfabeta. Sumiyati dan Sumarwanto. 2017. "Budi Pekerti". Modul. Kemdikbud.

Supardi. 2014. Kinerja Guru. Jakarta : Rajagrafindo Persada.

Suwendra, Wayan. 2017. Murid Bandel Salah Siapa?. Bali

: Nilacakra.

Syarbini, Amirulloh dan Khusaeri, Akhmad. 2012. Metode Islam dalam MembinaAkhlak Remaja. Jakara : Alex Media Komputindo.

Wohlstetter, P., Van Kirk, An, Robertson, PJ, \& Mohrman, SA. 1997. "Organizing for successful School Based Management". Association for Supervision and Curriculum Development.1250 N. Pitt Street, Alexandria, VA 22314-1453

Yaumi. 2018. Pendidikan Karakter. Jakarta : Kencana Prenada Media Group

Yumni, A. 20018. "Membentuk Kepribadian Ulul Albab Sebagai Orientasi Pendidikan Islam". Nizhamiyah, vol 8 No 2

Zai, Labibah dan Iskandar, Moh.. 2014. "Modernisasi Pendidikan pada Pesantren Gontor dan Dampaknya terhadap Masyarakat Ponorogo (1926-1945)". Jurnal Universitas Indonesia

Zarkasyi, Syukri, Abdullah. 2005. Gontor dan Pembaharuan Pendidikan Pesantren. Jakarta : rajagrafindo. 